

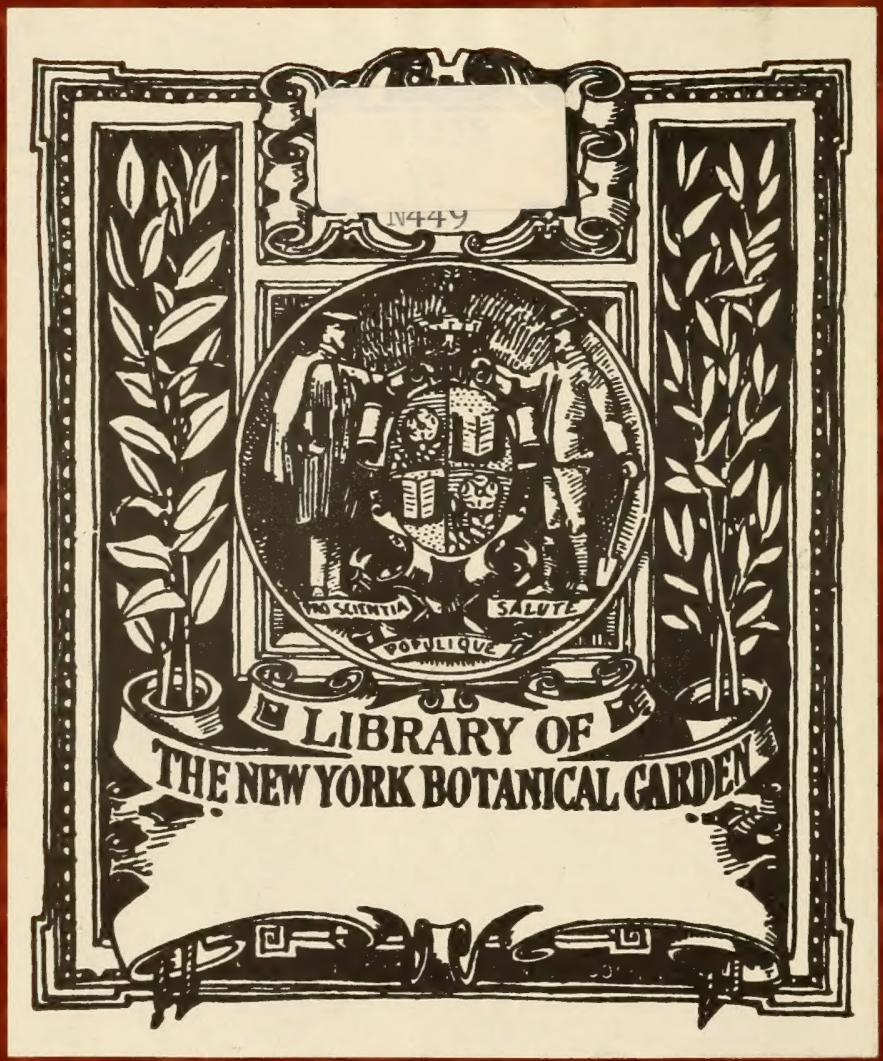




\section{20, Itonse}

REPORT OF THE STATE BOTANIST I9I5

\section{WARREN COUNTY}

\section{Elymus glaucus Buckley}

Warrensburg. Charles H. Peck, July. Determined by Prof. A. S. Hitchoock, to whom was submitted a large number of undetermined grasses collected by Professor Peck. The range given for this species is "Ontario and Michigan to British Columbia, Colorado and California." The Warren county collection constitutes not merely a new species for the state flora but a remarkable eastward extension to the known range of the species.

\section{Pyrola asarifolia Michx.}

Bog near Horicon. Dr Charles H. Peck, July. The exact year is not given, but the specimens were detected amongst some undetermined material collected between 1907 and rgio.

\section{WYOMING COUNTY}

\section{Cathartolinum sulcatum (Riddell) Small}

Near Portageville. Dr Charles H. Peck, July Igo8. Detected among the undetermined specimens of Professor Peck's collecting, and rather easily distinguished by the united styles.

\section{Lathyrus ochroleucus Hook.}

Near Portageville. Dr Charles H. Peck, May 1905. This must be regarded as one of the rare species of the state flora. It was collected nearly three-fourths of a century ago at Watertown, Jefferson county, by Crawe, and in Paine's Catalogue of the Plants of Oneida County and Vicinity two additional localities are mentioned, namely, Gorham, Ontario county (Sartwell), and Monroe county (C. M. Booth). In addition to these stations it has been collected at Penn Yan, Sartwell (in Nat. Herb.) ; western New York, Sartwell (in Gray Herb.) ; Lake Chautauqua, J. R. Churchill (in Gray Herb.) ; Ithaca, Tompkins county by Charles S. Sheldon in I878 (N. Y. State Herb.); at Belfast, Allegany county, and Carrollton, Cattaraugus county, by Charles H. Peck. With the exception of the Watertown locality, its range appears to be confined in this State to the western and southwestern counties.

The species was collected at Belleville, Ontario, June 1877 , by Professor Macoun, a station even farther north than Watertown. Its distribution in New York State is shown by the accompanying map. 


\section{A BIBLIOGRAPHY OF THE BOTANY OF NEW. YORK STATE}

One of the signs of progress in botany is the increasing attention given to the study of local vegetation and its ecological relations. A local flora has been published for nearly every section of the State in addition to a large number of county and sectional floras, which for the most part are exceptionally complete. The number of published papers dealing with various phases of local botany in this State is very large and one of the disadvantages to be encountered in the study of local flora problems is the difficulty of locating quickly the references to the published literature dealing with a given locality or section.

The bibliography here presented aims to group the titles bearing upon the subject in such a manner as to show the nature, quantity and authorship of the various studies upon the flora of the State and its natural and political subdivisions.

Citations dealing with economic botany (agriculture), plant pathology and forestry have been for the most part omitted, although it is obviously difficult to draw a line of distinction, especially where record is made in such articles to native species of fungi or flowering plants constituting an original observation or addition to the flora of some section of the State. Upon this ground alone have several titles dealing with plant pathology, agriculturę and forestry been admitted.

Since the aim of this bibliography is to present the citations by localities rather than by authors, the arrangement takes the following order:

I New York State in General

2 State Botanist's Reports

3 Adirondack Mountains

4 Catskill Mountains

5 Central New York

6 Hudson River Valley

7 Long Island

8 Susquehanna Valley

9 Western New York

Io Citation of Titles by Counties

Index to Citations by Authors

CURRENT FLORAS OF THE NORTHEASTERN STATES

Britton. Manual of the Flora of the Northern States and Canada. $3 \mathrm{~d}$ edition, revised and enlarged. 1907 
Britton \& Brown. Illustrated Flora. 3 v. 2 d edition, revised and enlarged. I9I3

Robinson \& Fernald. Gray's New Manual of Botany. Igo8

Stevens. An Illustrated Guide to the Flowering Plants of the Middle Atlantic and New England States. I9Io

\section{NEW YORK STATE}

Catalogue of the Plants Indigenous to the State of New York. Jacob Green. Transactions of the Society for the Promotions of Useful Arts. V. I, p. 9I-I36. Albany I8I4

Trees, Shrubs, Plants, \&c. (of New York). James Macauley. In "Natural, Statistical and Civil History of the State of New York." V. I, p. 52I-39. New York IS29

A Notice of Some New, Rare; or Otherwise Interesting Plants, from the Northern and Western Portions of the State of New York. Asa Gray. Ann. Lyc. Nat. Hist. N. Y. 3:22 I-38. I836 Catalogue of Plants (of New York State). John Torrey. 4th Annual Report Geological Survey New York. Assembly Document no. I6I. p. 9-10 (ed. 2, p. II-I2). I837. Assembly Doc. no. 5o. p. II 3-97. Jan. 24, I8.40

Flora of New York State. John Torrey. 2v. 4to., p. 484 and $572 ; \mathcal{X}$ I6I plates. Albany I 843

V. I. I $2+484$ p. 72 pl. I 843.300 copies with hand-colored plates.

V. 2. 572 p. 89 pl. 1843.300 copies with hand-colored plates. Catalogue of the Medicinal Plants, Indigenous and Exotic, Growing in the State of New York. Charles A. L.ee. Svo., pamph., p. 64. New York 1848

Catalogue of the Plants of the State of New York, of Which Specimens Are Preserved in the Cabinet at Albany. John Torrey. 2d Annual Report of the Regents on the Cabinet (for I848), p. 39-64. I849

Index to Volumes in the State Cabinet Containing the Plants of New York. L. C. Beck. Annual Report of the New York State Museum (for I849), p. I57-66. I850. The same report (for 1849 ) revised ed., p. I6I-72. I850

List of Plants Described in the State Flora, and of Plants Discovered and Collected since the Publication of the Flora. John Torrey. p. I-6I. Catalogue of the Cabinet of Natural History of New York. Albany I866 
Facts and Observations Touching the Flora of the State of New York. By One of the Regents (G. W. Clinton). ISth Annual Report of the Regents on the Cabinet, 197-205. 1865. I9th Annual Report of the Regents on the Cabinet, 72-80. 1866 Catalogue of Mosses Presented to the State of New York (Mainly from Rensselaer County). Charles H. Peck. Igth Annual Report of the Regents on the Cabinet, I93-96. Albany I866 List of Mosses of the State of New York. Charles H. Peck. Igth

Annual Report of the Regents on the Cabinet, 42-70. 1866 Facts and Observation Touching the Flora of the State of New York. Charles H. Peck. 2oth Annual Report of the Regents on the Cabinet, 403-10. I867. Reprinted on pages I59-66 of the revised (quarto) edition of the same report, dated I868 but not published until I870

Species (plants found) Growing Spontaneously in the State and not before Reported. Charles H. Peck. 22d Annual Report of the Regents on the Cabinet, 52-106. I869. These lists have been continued annually in the succeeding reports of State Botanist, Charles H. Peck, until I9I3. (See State Botanist's Reports)

Fungi. Charles H. Peck. Albany Institute Trans., 6:209-26. I870 Synopsis of New York Uncinulae. Charles H. Peck. Albany Institute Trans., 7:213-I7. I pl. I872

New Stations for Rare Plants. Remarks and Observations. Charles

H. Peck. 23d Report of the Regents on the Cabinet, I873. Continued under these titles in succeeding reports and bulletins of the New York State Museum. (See State Botanist's Reports)

Report on Botany. Charles H. Peck. Albany Institute Trans., $7: 35-43 ;$ I86-204. I872. 8:152-56. I876

The Black Spruce. Charles H. Peck. Albany Institute Trans., $8: 283^{--301 . ~ I 876 ~}$

Parasitic Fungi of New York and Their Supporting Hosts. Charles H. Peck. 29th Annual Report of the New York State Museum, 7I-82. I878.

The Ferns of New York. Benjamin D. Gilbert. Utica Herald. October I8, I878

List of the Ferns of New York State. William H. Leggett. Bul., Torrey Club, 6:I878. Addenda by L. M. Underwood. 1. c. 8:78-79. I880

New York Fungi. Mordecai Cubitt Cooke. Grevillea 8:117-19. I 880 
New York Carices. Charles H. Peck. 35th Report of the New York State Museum, I47-49. I882.

United States Species of Lycoperdon. Charles H. Peck. Albany Institute Trans., 9:285-3I8. I 879

Contains numerous references to New York species.

Contributions to the Botany of the State of New York. Charles H. Peck. Bu1., New York State Museum, 2:I-66. 2 pl. Albany I887

Fertilization of Wild Flowers. Charles H. Peck. Albany Institute Trans., I I :I 55-68. I887

List of the New York Pyrenomycetous Fungi. Charles H. Peck. Bu1., N. Y. Museum, 2:49-56. I887

Names of New York Pyrenomycetous Fungi. Charles H. Peck. New York State Museum Bul. 2, p. 49-56. I887.

Fungi Destructive to Wood. P. H. Dudley. 4Ist Annual Report of the State Museum of Natural History (for I887), p. 86-94. I888. 4Ist Annual Report of the State Botanist, p. 45-46. I890

Boleti of the United States. Charles H. Peck. New York State Museum Bulletin, 8 p. 7I-I66. I889

Contains numerous references to New York species.

Edible Wild Fruits of New York. Charles H. Peck. Albany Institute Trans., I2:83-102. I889. Fruit Growers Journal (Cobden, Il1.) 6:I6, June I5, I889; 6:I7, July I, I889; 6:I8, July I5, I889; 6:19, August I, I889; 6:20, August 15, I889; $6: 21$, September I, I889

Native Trees of New York. Charles H. Peck. Annual Report of the Forest Commission of New York (for I89I), p. I03-5. 1892. Reprinted in Annual Report of the Forest Commission of New York (for I893), p. 244-46. I894

Weeds. Charles H. Peck. Albany Institute Trans., I2: 25I-65. I 893

List of New York Fungi Represented at the World's Columbian Exposition at Chicago, in the Horticultural Building. Charles H. Peck. 47th Report, p. 43-48. I894

New York Species of Carex. E. C. Howe. Report of State Botanist for I894. (From 48th Annual Report of the New York State Museum), p. 20-104. I895. Same, Museum Report 48 (for I894), I:II8-202. 1895 
Edible and Poisonous Fungi of New York. Charles H. Peck. 48th Annual Report of the New York State Museum, p. I05-24I. 43pl. Albany 1896

Continued under this title in succeeding annual reports of the State Botanist in Annual Reports and Bulletins of the State Museum to I9I3, the total number of plates being I32. (See State Botanist's Reports).

Dryopteris Simulata in New York State. Willard Nelson Clute.

Fern Bulletin, 7:9I-92. I899

Report of the State Botanist on Edible Fungi of New York.

Charles H. Peck. New York State Museum Memoir 4 (v. 3), p. I29-234, pl. 44-68. Albany 1900

Notes on Some Type Specimens of Myxomycetes in the New York State Museum. W. C. Sturgis. Connecticut Academy of Arts and Science Trans., I0:463-90. pl. 60, 6r. 1900

Notes from the Botanical Department (on fungi). F. C. Stewart and H. J. Eustace. New York Agricultural Experiment Station Bul. 200. Geneva IgoI

A History of the Lumber Industry in the State of New York. William F. Fox. United States Department of Agriculture, Bureau of Forestry, Bul. 34, p. 59. Washington 1902

Studies in North American Discomycetes. II. Some New or Noteworthy Species from Central and Western New York. Elias Judah Durand. Torrey Club Bul. 29, p. 458-65. July 25, 1902 The Fern Flora of New York. Benjamin D. Gilbert. Fern Bul., I I :97-105. 1903.

New York Species of Crataegus. Charles H. Peck. New York State Museum Bul. 75, p. 35-57. 1904

A Key to the Genera of Woody Plants in Winter, Including Those with hardy Representatives found Growing Wild or in Cultivation Within New York State. K. M. Wiegand and F. W. Foxworthy. pamph., p, I-27. Ithaca I904. Second ed., p. I-33. I906. Third ed., p. I-33. I908

List of New York Fungi. F. L. Stevens. Journal of Mycology I3:67-72. 1907

Notae Mycologicae. P. A. Saccardo. Annales Mycologici 6: 553-69. 1908

Describes fourteen species of fungi from New York.

New York Species of Crataegus from Various Localities. Charles Sprague Sargent. New York State Museum Bul. I22, p. II530. 1908

Asplenium Ebenoides in New York. Stewart H. Burnham. Fern Bul. I6:III-I3. I908 (January I909) (Hartford, Washington county, and Saugerties, Ulster county) 
List of Species and Varieties of Fungi Described by C. H. Peck, State Botanist. (Charles H. Peck). New York State Museum Bul., I3I, p. 59-I90. I909

Notes on New York Plant Diseases I. F. C. Stewart. New York Agricultural Experiment Station Bul. 328. Geneva I9Io

List of Edible, Poisonous and Unwholesome Mushrooms hitherto Figured and Described by C. H. Peck, State Botanist. (Charles H. Peck). New York State Museum Bul. I39, p. 78-89. I9IO

A Bibliography of the Genera whose New York Species Have been Collated with Descriptions in the State Botanist's Reports

(Fungi). (Charles H. Peck). New York State Museum Bul. I39, p. 87-89. - I9Io

Reference is made to the following genera: Aecidium, Agaricus, Amanita, Armillaria, Boletus, Boletinus, Cantharellus, Craterellus, Claudopus, Clavaria, Clitocybe, Clipopilus, Collybia, Coprinus, Cortinarius, Crepidotus, Entoloma, Flammula, Galera, Hebeloma, Helvella, Hygroporus, Hypholoma, Lactarius, Lentinus, Lepiota, Leptonia, Lycoperdon, Marasmius, Mycena, Naucoria, Odontia, Omphalia, Panaeolus, Paxillus, Pholiota, Pleurotus, Pluteolus, Pluteus, Psathyrella, Psilocybe, Puccinia, Russula, Spathularia, Strobilomyces, Trametes, Tricholoma, Xylaria.

Forestry and Forest Resources in New York. F. A. Gaylord. Conservation Commission of New York, Bul. I. Albany I9ı2 Wild Flowers of New York. Chester Albert Reed. p. I-46. Mohonk Lake, N. Y., I9I2. Illustrated in color

Crataegus in New York. Charles Sprague Sargent. New York State Museum Bul. I67, p. 53-124. I913

Tree Diseases. Clifford H. Pettis. Second Annual Report of the Conservation Commission of New York, p. 97-99. 3 pl. Albany I9I3

Braun's Holly Fern. Stewart H. Burnham. American Fern Journal, 4:I-5. I9I4

New or Interesting Species of Fungi. Homer D. House. New York State Museum Bul. I76, p. I9-2r. I9I5. 1. c. Bul. I79, p. 26-32. I9I 5

The Herbarium of Charles S. Sheldon. Homer D. House. New York State Museum Bul. I79, p. 22-25. I9I5

Includes a list of the rarer New York plants therein.

New York Species of Marasmius. L. H. Pennington. New York

State Museum Bul. I79, p. 52-79. I9I5

Fungi Noveboracenses a cl. H. D. House imprimis collecti. P. A. Saccardo. Annales Mycologici, I3:II5-22, I9I5 
The Development of the Vegetation of New York State. William L. Bray. p. I86. I map in color, 52 fig. Technical Publication No. 3, New York State College of Forestry at Syracuse University. Nov., 1915. (Vol. XVI, No. 2. Syracuse University Quarterly Publications).

\section{STATE BOTANIST'S REPORTS}

Except where otherwise indicated, Dr Charles Horton Peck is the author of the contents of the State Botanist's Reports from I867 to I9I2. The reports of I9I3, I9I4 and 1915 are by Homer D. House.

Bound also with Museum Reports 2I-55, of which they form a part; the first Botanist's report appeared in the 2Ist Museum Report and is numbered 2I. Reports 2I-24, 29, 3I-4I were not published separately.

Report of the Botanist (for I867). From the 2Ist Annual Report of the Regents on the New York State Cabinet of Natural History (for I867), p. 23-24. I87I

Report of the Botanist (for I868). From the 22d Annual Report of the Regents on the New York State Cabinet (for I868), p. 25-106. I869

Species growing spontaneously in the State and not before reported, p. 52-105.

Report of the Botanist (for I869). Appendix C. 23d Report of the Regents on the New York State Cabinet (for I869), p. 27I35. pl. I-6. I 873

List of plants found on the exposed summit of Mount Marcy, p. 43-44.

Plants found growing spontaneously in the State and not before reported, p. 49-133 (including synopsis of genera of Agaricaceae and Boletus).

New Stations of Rare Plants and Notable varieties, p. 133-35.

Report of the Botanist (for I870). From the 24th Report of the

Regents on the New York State Museum of Natural History

(for I870), p. 4I-IO8. p1. I-4. I872

Plants found growing spontaneously in the State and not before reported, p. 56-103.

The genus Clavaria, p. 104-5.

The genus Aecidium, p. 105-8.

Report of the Botanist (for 187I). From the 25th Annual Report of the New York State Museum of Natural History (for I 87 I ), p. 57-I23. pl. I-2. I 873

Plants found growing spontaneously in the State and not before reported, p. 69-106.

New stations of rare plants, remarkable varieties and observations. p. Io7-9. Synopsis of the New York Pucciniae, p. IIo-23. 
Report of the Botanist (for 1872). From the 26th Annual Report of the New York State Museum of Natural History (for I872), p. 35-9I. I 874

Plants found growing spontaneously in the State and not before reported, p. 48-87.

New stations of rare plants, remarks, and observations, p. 87-9I.

Report of the Botanist (for 1873). From the 27th Annual Report of the New York State Museum of Natural History (for I873), p. 73-II6. 2pl. I875

Plants found growing spontaneously in the State and not before reported, p. 89-III.

New stations of rare plants, remarks and observations, p. III-II6 (including synopsis of Ustilago).

Report of the Botanist (for I874). From the 28th Annual Report of the New York State Museum of Natural History (for I874, p. 3I-88. 2pl. I 876

Plants, indigenous and introduced, not before reported, p. 46-82.

New stations of rare plants, remarks and observations, p. 82-88.

(The State Museum edition, published in I879.)

Report of the Botanist (for 1875). From the 29th Annual Report of the New York State Museum of Natural History, p. 29-82.

2 pl. 1878

Plants not before reported, p. 38-63.

Plants previously rēported, remarks and observations, p. 63-7I.

Parasitic fungi of New York and their supporting plants, p. 7I-82.

Report of the Botanist (for I876). From the 3oth Annual Report of the New York State Museum, p. 23-78. 2 pl. 1878

Species not before reported, p. 37-67.

Remarks and observations, p. 68-78.

Report of the Botanist (for I877). From the 3Ist Annual Report of the New York State Museum, p. I9-60. I879

Plants not before reported, p. 30-5I.

New stations, notes and observations, p. 5I-54.

List of New York Myxogasters, p. 55-58.

New York species of Helvella, p. 59-60.

New York species of Xylaria, p. 60.

Report of the Botanist (for I878). From the $32 \mathrm{~d}$ Annual Report of the New York State Museum, p. I7-72. 1879

Plants not before reported, p. 24-52.

Remarks and observations, p. 52-58.

New York species of Lycoperdon, p. 58-72.

Mosses of Caledonia creek, N. Y., p. 73-74.

Report of the Botanist (for I879). From the 33d Annual Report of the New York State Museum, p. I I-49. 2 pl. I88o Plants not before reported, p. 17-34. 
Remarks and observations, p. 35-38.

New York species of Amanita, p. 38-49.

Report of the Botanist (for I880). $3 t_{\text {th }}$ Annual Report of the

State Museum of Natural History, p. 24-58. 4 pl. I88r

Plants not before reported, p. 4I-53.

Remarks and observations, p. 53-58.

Report of the Botanist (for I88r). 35th Annual Report of the

New York State Museum, p. 125-64. 1884

Species not before reported, p. I3I-45.

Remarks and observations, p. I45-47.

New York Carices, p. I47-49.

New York species of Lepiota, p. 150-64.

Report of the Botanist (for 1882). 36th Annual Report of the

New York State Museum of Natural History, p. 27-49. I 883

New stations, remarks and observations, p. 35-40.

New York species of Psalliota, p. 4i-49.

Report of the Botanist. (for I883). From the 37th Annual Report

of the New York State Museum, p. 63-68. I884

The titles of the first four articles enumerated below were given on page 65. The articles, however, were printed in the following publication: "Contribution to the Botany of the State of New York." Charles H. Peck. New York State Museum Bul. 2, p. I-66. 2 pl. May I887.

Descriptions of new species of fungi, p. 5-24.

Additions to the flora of the State of New York in 1883, with remarks and observations, p. 25-28.

New York species of Paxillus, p. 29-33.

New York species of Cantherellus, p. 33-43.

New York species of Craterellus, p. 44-48.

Names of New York species of Pyrenomycetous fungi, p. 49-56.

New York species of Viscid Boleti, p. 57-66.

Report of the Botanist (for I884). From the 38th Annual Report of the New York State Museum of Natural History, p. 77-I 38. 3 pl. I 885

Plants not before reported, p. 83-106.

Remarks and observations, p. 106-II.

New York species of Lactarius, p. II I-33.

New York species of Pluteus, p. I33-38.

Report of the Botanist (for I885). From the 39th Annual Report of the Trustees of the State MIuseum of Natural History (for I 885 ), p. 30-73. 2 pl. I 886

Plants not before reported, p. 38-53.

Remarks and observations, p. 53-58.

New York species of Pleurotus, p. 58-67.

New York species of Claudopus, p. 67-69.

New York species of Crepidotus, p. 69-73. 
Report of the Botanist (for 1886). From the 4oth Annual Report of the Trustees of the State Museum of Natural History (for I 886), p. 39-77. I887

Plants not before reported, p. 52-7I.

Notes and observations, p. 72-77.

Report of the State Botanist (for 1887). From the 4Ist Annual Report of the Trustees of the State Museum of Natural History, p. 49-I22. I888

Plants not before reported, p. 56-8I.

Remarks and observations, p. $8 \mathrm{I}-86$.

Fungi Destructive to Wood, by P. H. Dudley, p. 86-94.

Botanical index to New York State Museum Reports 22 to 38, p. 94-122.

Annual Report of the State Botanist (I888). From the 42d Report of the New York State Museum. Bot. ed., p. I-48. 2 pl. I 889

Species not before reported, p. I5-35.

Remarks and observations, p. 35-39.

New York species of Clitopilus, p. 39-46.

Annual Report of the State Botanist (I889). From the 43d Report of the New York State Museum. Bot. ed., p. I-48. 4 pl. I 890

Plants not before reported, p. I6-36.

Remarks and observations, p. 36-40.

New York species of Armillaria, p. 30-45.

Fungi causing decay of timbers (a letter from P. H. Dudley), p. 45-47.

Annual Report of the State Botanist (I890). From the 44th Report of the New York State Museum, p. II5-87. p1. I-4. 'I892. Bot. ed., p. I-75. I89I

Species of plants not before reported, pl. I-4 (I89I), p. I5-30.

Remarks and observations, p. $30-38$.

New York species of Tricholoma, p. 38-64.

Fungi of Maryland (Mary E. Banning) (C. H. Peck), p. 64-75.

Annual Report of the State Botanist (I89I). From the 45th Report of the New York State Museum, p. 63-102. I892. Bot. ed., p. I-42. I893

Plants not before reported, p. $17-25$.

Remarks and observations, p. 25-3I.

New York species of Omphalia, p. 32-42.

Annual Report of the State Botanist (I892). From the 46th Report of the New York State Museum, p. 83-I49. I893. Bot. ed., p. I-69. I893

Species not before reported, p. 18-36.

Extralimital species, p. $37-40$.

Notes and observations, p. 40-58.

New York species of Pluteolus, p. 58-6r.

New York species of Galera, p. 6I-69. 
Annual Report of the State Botanist ( ISO3). From the 47th Report of the New York State Museum, p. I29-74. I894. Bot. ed., p. I-48. I 894

Species not before reported, p. I6-26.

Remarks and observations, p. 27-43.

List of New York fungi represented at the World's Columbian Exposition at Chicago, p. $43-48$.

Report of the State Botanist (1894). From the 48th Report of the New York State Museum, p. IOI-337 pl. A and I-43. I895.

Bot. ed., p. I-238. P1. A and I-43. I 806

Species not before reported, p. II-I7.

Remarks and observations, p. I7-20.

New York species of Carex, by E. C. Howe, p. 20-104.

Edible and Poisonous Fungi of New York (p1. A \& I-43), p. I05-238.

(Catalogue of New York Woods (Mus. ed.), p. 16-20).

Annual Report of the State Botanist (I895). From the 49th Report of the New York State Museum, I:I7-83. I897. Bot. ed., p. I-70. 1896.

Species not before reported, p. 15-24.

Remarks and observations, p. 25-32.

New York species of Collybia, p. 32-55.

Edible Fungi (pl. 44-49), p. 56-69.

Annual Report of the State Botanist ( 806 ). From the 50 th Report of the New York State Museum, p. 77-159. I898

Species of plants not before reported, p. 92-II9.

Remarks and observations, p. II9-33.

New York species of Flammula, p. 133-42.

Index to reports $34-48$, p. I $43-59$.

Report of the State Botanist (I897). Reprinted from 5ist Annual

Report of the New York State Museum, p. 267-32I. I899

Species not before reported (p1. A, B), p. 277-96.

Remarks and observations, p. 296-300.

Edible fungi (pl. 50-56), p. 300-12.

Report of the State Botanist (I 898 ). New York State Museum

Bul. 25, p. 618-88. 1900

(Reprinted from 52d Report of the New York State Museum). List of changed names (in Illustrated Flora) from those of Gray's Manual, p. 628-42.

Species not before reported, p. $642-50$.

Remarks and observations, p. $65 \mathrm{I}-56$.

Plants of the summit of Mount Marcy, p. 657-73.

Edible fungi (pl. 57-6i), p. 673-82.

The descriptions and illustrations of edible and unwholesome species of fungi contained in the 49 th, 5 Ist and $52 \mathrm{~d}$ reports have been revised and rearranged and combined with others more recently prepared and constitute Museum Memoir 4. 106 p. 25 pl. Igoo. Same, Museum Report 53 (for I 899) 2:129-234. 25pl. 1901. 
Report of the State Botanist (1899). Reprinted from the $53 \mathrm{~d}$

Report of the New York State Museum (for I900), p. 82I-67 Species not before reported (pl. A-D), p. 835-49.

Remarks and observations, p. 849-58.

Plants of Bonaparte swamp, p. 858-6I.

Plants of North Elba, New York State Museum Bul. 28, p. 65-266.

Report of the State Botanist (I900). Reprinted from the 54th Annual Report of the New York State Museum, p. I29-99. pl. E-I. pl. 69-76. 1902

Species not before reported (pl. E-I), p. 143-57.

Remarks and observations, p. 158-72.

Edible fungi (pl. 69-76), p. I73-86.

Report of the State Botanist (I90I). New York State Museum Bul. 54. Ig02. Reprinted from the 55th Annual Report of the New York State Museum.

Species not before reported (pl. K, L), p. 944-57.

Remarks and observations, p. $957-66$.

Edible fungi (pl. 77-8I), p. 966-78.

Report of the State Botanist (1902). New York State Museum Bul. 67. 1903

Species not before reported (pl. M, N), p. 18-32.

Remarks and observations, p. 32-39.

Edible fungi (pl. 82-84), p. 39-47.

Plants of the Susquehanna valley and adjacent hills of Tioga county, by Frank E. Fenno, p. 47-160.

Rejort of the State Botanist (I903). New York State Museum Bul. 75. 1904

Species not before reported (pl. O), p. 12-22.

Remarks and observations, p. 22-27.

Edible fungi (pl. 84-86), p. 27-34.

New York species of Craetaegus, p. 35-57.

Supplementary list of plants of Susquehanna valley, by Frank E. Fenno, p. $57-60$.

Report of the State Botanist (1904). New York State Museum Bul. 94. 1905

Species not before reported (pl. P, Q, R), p. 19-35.

Remarks and observations (pl. 87-93), p. 35-44.

Edible fungi, p. 44-50.

Report of the State Botanist (1905). New York State Museum Bul. 105. 1906

Species not before reported (pl. S, T), p. I5-30.

Remarks and observations, p. 30-36.

Edible fungi (p1. 94-Io3), p. 36-44.

Species of Crataegus found within twenty miles of Albany, by C. S. Sargent and C. H. Peck, p. 44. 
Report of the State Botanist (Igor). New York State Museum Bul. II6. 1907

Species not before reported, p. 17-3r.

New extralimital species of fungi, p. 3i-33.

Remarks and observations, p. 33-38.

Edible fungi (pl. 104-9), p. 38-45.

New York species of Hygrophorus, p. 45-67.

New York species of Russula, p. 67-98.

Report of the State Botanist (I907). New York State Museum

Bul. I22. 1908

Species not before reported, p. 17-25.

Some additions to the Crataegus flora of western New York, by C. S. Sargent, p. 26-83.

Notes on a collection of Crataegus made by $\mathrm{Mr}$ G. D. Cornell in the neighborhood of Cooper Plains, Steuben county, N. Y., by C. S. Sargent, p. 84-II4.

New York species of Crataegus from various localities, by C. S. Sargent, p. II5-30.

Remarks and observations, p. I3I-35.

Edible fungi (pl. I10-I4), p. I35-4I.

New York species of Pholiota, p, I4I-58.

Latin description of new species of plants, p. I58-60.

Report of the State Botanist (I908). New York State Museum Bul. I3I. rgo9

Species not before reported.(p1. U), p. I8-28.

Remarks and observations, p. 29-32.

New extralimital species of fungi (pl. V), p. 33-38.

Edible fungi (pl. II7-20), p. 34-42.

New York species of Lentinus, p. 42-47.

New York species of Entoloma, p. 47-58.

List of species and varieties of fungi described by C. H. Peck, p. 59-190. Report of the State Botanist (Ig09). New York State Museum Bul. I39. I910

Species not before reported, p. 19-32.

Remarks and observations, p. 33-37.

Edible fungi (pl. II7-20), p. 37-42.

New species of extralimital fungi (pl. W, X, Y, Z), p. 42-48.

New York species of Inocybe, p. 48-67.

New York species of Hebeloma, p. 67-78.

List of edible, poisonous and unwholesome mushrooms hitherto figured and described by C. H. Peck, p. 78-86.

List of genera whose New York species (chiefly) have been collated with descriptions in the State Botanist's reports cited, p. 87-89.

Reprort of the State Botanist (I9IO). New York State Museum

Bul. I50. I9I I

Species not before reported, p. 23-4I.

Remarks and observations, p. 42-49. 
New species and varieties of extralimital fungi, p. 50-65.

Edible fungi (p1. I2I-23), p. 65-69.

Cranberry and Averyville marshes, p. 69-73.

New York species of Hypholoma, p. 73-84.

New York species of Psathyra, p. 84-86.

Report of the State Botanist (I9II). New York State Museum

Bul. 157 . 1912

Species not before reported, p. $21-36$.

Remarks and observations, p. 37-44.

New species and varieties of extralimital fungi, p. 45-52.

Edible fungi (pl. I24-30), p. 53-58.

New York species of Clitocybe, p. 59-89.

New York species of Laccaria, p. 90-93.

New York species of Psilocybe, p. 94-I05.

Latin descriptions of new species and varieties, p. Io6-16.

Report of the State Botanist (IgI2). New York State Nuseum Bul. 167. I9I3

Species not before reported, p. 23-33.

Remarks and observations, p. $34-37$.

New species of extralimital fungi, p. 38-50.

Edible fungi (pl. I3I-32), p. 5I-52.

Poisonous fungi (pl. X), p. 52 .

Crataegus in New York, by C. S. Sargent, p. 53-I24.

Report of the State Botanist (I913). New York State Museum Bul. I76. I9I5

New or interesting species of fungi I, p. I9-2I.

Notes upon local floras I, p. 22-44.

An odd form of hypertrophy in Arbor vitae, p. 45-46.

Certain features of German forestry, p. 47-74.

Report of the State Botanist (I9I4). New York State Museum Bul. I79. I9r 5

The herbarium of Charles S. Sheldon, p. 22-25.

New or interesting species of fungi II, p. 26-32.

New or noteworthy extralimital fungi, p. 33-37.

Western plants introduced at Rochester, p. 38-39.

Notes upon local floras II, p. 40-5I.

New York species of Marasmius, by L. H. Pennington, p. 52-79.

The fungi of North Elba, by C. H. Kauffman, p. 80-104.

\section{ADIRONDACK MOUNTAINS}

(See also Franklin, Herkimer, Essex, Warren and Lewis counties)

The Flora of the Adirondacks. George Thomas Stevens. Albany Institute Trans., 6:67-82. 1870

Notes on the Adirondacks. (Hamilton county). Albert Nelson

Prentiss. Torrey Club Bul. Io, p. 43-45. I883 
The Adirondack Black Spruce. II. F. Fox. Annual Report of the Forest Commission of New lork for 1Sy)t, p. 12 I-1)S. I\$95 The Spruces of the Adirondaclis. Charles 11. Peck. Pamphlet, I 3 pages. Albany I 898

Read before the Albany Institute November 16, 1897.

The Adirondack Spruce, I Study of the Forest in Ne-Ha-Sa-Ne Park. Gifford Pinchot. I57 pages. New York I898

Practical Forestry in the Adirondacks. Henry S. Graves. United States Department of Agriculture, Division of Forestry, Bul. 26, p. I-85. Washington I899

A Note of the "Flowering" of the Lakes in the Adirondacks.

Marshall Avery Howe. Torreya, 3:150-54. I903

The Plant Formation of the Adirondack Mountains. John W.

Harshberger. Torreya, 5:187-94. I905

\section{CATSKILL MOUNTAINS}

(See also Greene and U1ster counties)

A List of the Trees and Shrubs Collected (in the Catskill Mountains). Edgar Alexander Mearns. United States National Museum Proc., 2 I :343. I898

Mosses of the Catskill Mountains, N. Y. Elizabeth Gertrude Britton. Torreya, I :84. I90 I

Notes from the Catskills. J. C. Buchheister. Fern Bul. I I :I5-I6. 1903

The Plant Formations of the Catskills. John W. Harshberger. Plant World, 8:276-8I. I905

\section{CENTRAL NEW YORK}

New Stations of Rare Plants (in Central New York). David Starr Jordan. American Naturalist, 6:362. June 1872

Notes from Central New York. John Herman Wibbe. Torrey Club Bul. Io:46-47. April I883

The Cayuga Flora. William R. Dudley. Cornell University Bul. 2:I32. Ithaca, I886. (Additions by K. M. Wiegand, Torrey Club Bul., 2 I : I76-77. I894)

Some Rare Myxomycetes of Central New York, with Notes on the Germination of Enteridium rozeanum. Flias J. Durand. Bot. Gaz., I9:89-95. I894

Buxbaumia indusiata Bridel, in Central New York. Elias I. Durand. Torrey Club Bul., 2 I :38-39. I894

The Hart's-tongue Fern in New York and Tennessee. William Ralph Maxon. Plant World, 3:129-32. I900 
On the Occurrence of the Hart's-tongue Fern in America. William Ralph Maxon. Fernwort Papers, 30-36. Published by the Linnaean Fern Chapter, Binghamton, Ig0o

Eleocharis diandra in Central New York. J. V. Haberer. Rhodora, $2: 61$. Ig00

The Ternate Botrychia in Central New York. Benjamin D. Gilbert. Fern Bulletin, 9:25-28. I90 I

The Acaulescent Violets of Central New York. Homer D. House. Torreya, 3:49-54. I903

Notes upon the Orchids of Central New York. Homer D. House. Torreya, 3:49-54. 1903

Further Notes on the Orchids of Central New York. Homer D. House. Torrey Club Bul., 32:373-82. I905

The localization of plants in the Finger Lakes Region and the Adjacent Ontario Lowlands of Central New York. W. W. Rowlee. Torreya, $7: 69-73 . \quad 1907$

Lowland of Central New York. Isaiah Bowman. Forest Physiography p. 707-20. New York. IgI I (John Wiley \& Sons)

\section{HUDSON RIVER VALLEY}

Note on Some Rarer Plants of the Valley of the Hudson. James H. F. Merrill. Torrey Club Bul., I3:6. I 886

Notes on the Flora of the Hudson Highlands. William Whitman Bailey. Torrey Club Bu1., I3:60, 61. April I886

A Fruit Disease Survey of the Hudson Valley in I899. F. C. Stewart and F. H. Blodgett. New York Agricultural Experiment Station Bul. I67. Geneva I899

Native Trees of the Hudson River Valley. Norman Taylor. New York Botanical Garden Bul., 7 :90-I47. I909

The Highlands of the Hudson Forest Reservation. F. Frank Moon. I5th Annual Report of the New York Forest, Fish and Game Commission, Io3-2I. Map. Albany

Also reprinted, pamphlet.

\section{LONG ISLAND}

On the Northward Extension of the New Jersey Pine Barren Flora on Long and Staten Islands. Nathaniel Lord Britton. Torrey Club Bul., 7:8I-83. July I880

Check List of the Marine Algae Based on Specimens Collected on the Shores of Long Island, from I839 to I885. Nicholas Pike. Torrey Club Bu1., I3:105-I5. I886

Reprinted, pamph., Io pages. I 886

Notes from Long Island. George D. Hulst. Torrey Club Bul. I8:I52, I 53. I $89 \mathrm{I}$ 
Notes from Long Island. Smith Ely Jelliffe. Science, 22:6. Isy3 Cryptogamic Notes from Long Island. Smith Ely Jelliffe.

I Torrey Club Bul., 2I :266-68. I894 (Musci)

2 Torrey Club Bul., 2I:489. 1894 (Hepaticae)

3 Torrey Club Bul., 22:274-75. I895 (Diatomaceae)

Orchids on Long Island. Augusta Schenck Kalbfleisch. Plant World, I:I77-79. 1898

The Flora of Long Island. Smith Ely Jelliffe. P. I-I63. I 899.

Additions in Torreya, 4:97-100. 1904

The June Flora of a Long Island Swamp. Anna MIurray Vail. Garden and Forest, $8: 282,283 . \quad 1895$

The Flora about Coldspring Harbor. Charles Benedict Davenport.

Science II, 8:687-88. November I8, I898

Also on pages 7 -IO of a repaged separate of the paper of which it constitutes a part.

The Violets on Long Island. William L. Fisher. Plant World, $3: 91-92.1900$

Note on a Long Island Moss. Elizabeth Gertrude Britton. Torreya, 2:91. 1902. Bryologist, 5:66-67. I902

Additions to the Recorded Flora of Long Island. A. J. Grout. Torreya, 2:49-53. I902

Notes on the Local Flora. Frederick William Kobbe. Torreya, $4: 68,69.1904$

Three New Violets from Long Island. Eugene P. Bicknell. Torreya, 4:I29-32. 1904

Additions to the Lichen Flora of Long Island. George Clayton Wood. Bryologist, 8:5I. May I, I905

Contribution to the Recorded Fungus and Slime-mould Flora of Long Island. Gerard Alston Reichling. Torreya, 5:85-87. May 25, 1905

A Long Island Cedar Swamp. Roland M. Harper. Torreya, 7:198-201. 1907

A New Utricularia from Long Island. John Hendley Barnhart. Torrey Club Bul., 34:579-82. I907

The White Cedar Swamp in Westem Long Island. Eugene P. Bicknell. Torreya, 8:27-28. I908

The First Botanic Garden on Long Island. C. Stuart Gager. Brooklyn Botanic Garden Record, I :97-99. I9I2 


\section{SUSQUEHANNA 'VALLEY REGION}

(See also under counties of the Susquehanna valley)

Flora of the Upper Susquehanna and Its Tributaries. Willard Nelson Clute. p. I-I42. Binghamton I898. Second ed. (with I6 page supplement), Igor

The Ferns and Fern Allies of the Upper Susquehanna Valley. Willard Nelson Clute. I2 mo., pamphlet, p. I-15. Binghamton 1898

\section{WESTERN NEW YORK .}

(See also under counties of the western part of the State)

Notes on New or Rare Fungi from Western New York. Charles Edward Fairman. Jour.- Mycol., 5 :78-80. June I889

Contributions to the Mycology of Western New York. The Fungi of Western New York. Charles Edward Fairman. Rochester Academy of Science Proc., I :43-54; p1. 3, 4. I89o

Notes on Western New York Woodlands. E. J. Hill. Garden and Forest, $8: 342,382-85$. I 895

Studies in North American Discomycetes. II. Some New or Noteworthy Species from Central and Western New York. Elias J. Durand. Torrey Club Bul., 29:45\&-65. 1902

Some New Fungi from Western New York. Charles Edward Fairman. Journ. Mycol., IO:229-3I. 1904

All from Orleans county.

Remarks on Some Fernworts of Western New York. E. J. Hill. Fern Bulletin, I2:I8-20. I904

Some Additions to the Crataegus Flora of Western New York. Charles Sprague Sargent. New York State Museum Bul. I22, p. 26-83. I908

Fern Notes from (western) New York. Mrs George B. Ayres. Fern Bulletin, I9:I5-16. I9I I

\section{Io CITATION OF TITLES BY COUNTIES}

\section{ALBANY COUNTY}

(Catalogue of the Plants of Albany County). J. S. Markle and Charles H. Peck. Bicentennial History of Albany. Published by Howell \& Tenney, p. 2I-29. . I886

Species of Crataegus Found within Twenty Miles of Albany. Charles Sprague Sargent and Charles H. Peck. New York State Museum Bul I05, p. 44-77. Albany I906

An Afternoon in the Helderbergs. Frank Dobbin. American Botanist, I2:78, 79. 1907 
Vegetation of the Escarpment near Indian Iadder. Ilomer D. House. 19th Annual Report of the American Scenic and Preservation Society, p. 357-59. I9I4

\section{BRONX COUNTY}

(See also New York county)

Some of the Rarer Plants of Our Northern Suburbs. Eugene P. Bicknell. Torrey Club Bul., 7:5I-54. I880

Local Cryptogamic Notes (Diatoms from Van Cortland Lake). Henry Clay Bennett and Smith Ely Jelliffe. Torrey Club Bul., 24:412. I897

Desmids from Bronx Park, New York. J. A. Cushman. Torrey Club Bul., 30:513-14. 1903

\section{BROOME COUNTY}

(See also Susquehanna valley region)

Broome County (N. Y.) Finds. Charles Frederick Millspaugh. Torrey Club Bul., I2:100-2. 1885

Notes from Binghamton, New York. Willard Nelson Clute. Torrey Club. Bul., 23:424. 1896

\section{CAYUGA COUNTY}

(See also Dudley's Cayuga Flora in the Central New York list)

A Catalogue of Plants Found in the Vicinity of Aurora, Cayuga County, During the Year I840. Analyzed and arranged at said place by George W. Schenck. Alexander Thompson. 54th Annual Report of the Regents, 224-26. Albany I84I

\section{CHAUTAUQUA COUNTY}

The Chautauqua Flora. Edward S. Burgess. Pamphlet, 37 pages. Clinton 1877

\section{CHEMUNG COUNTY}

Notes from Chemung County, New York. T. F. Lucy. Torrey Club Bul., 8:I I5 (I88I), 9:72 (I882), I0:8, 9 (I883)

\section{CHENANGO COUNTY}

Flora of Chenango County, N. Y.; Some Plants Not Previously Reported from That Region. Frederick Vernon Coville. Torrey Club Bul., $12: 52,53$. I 885 


\section{COLUMBIA COUNTY}

See also Flora of the Vicinity of New York by Norman Taylor, and citations under Hudson River valley.

(Catalogue of Plants Growing in the Vicinity of the City of Hudson). Cyrus M. Stebbins. Albany Institute Trans., I2-33, 34. 1830

A Catalogue of Indigenous Plants Found Growing in the Vicinity of Kinderhook Academy. W. V. S. Woodworth. 52d Annual Report of the Regents, 253-54. Albany 1839. 53d Annual Report of the Regents, 208-IO. Albany I840 (title not indicated for latter list)

Trees and Shrubs of New.York. (A list of 63 species from Lebanon Springs). Arthur Harrison. Swiss Cross, 2 :63. I887 The Rare Mosses of Bashbish Falls. Elizabeth Gertrude Britton. Torreya, I :9. I90I

The Flora of Copake Falls, New York. Sereno Stetson. Torreya, I3:I2I-33. I9I3

A Supplementary List of Plants of Copake Falls, New York.

Stewart H. Burnham. Torreya, I3:217-I9. I9I3

I9I3 Notes on the Flora of Copake Falls, New York. Sereno Stetson. Torreya, I4:42-45. I9I4

\section{CORTLAND COUNTY}

A Catalogue of Plants, Growing Spontaneously in the Vicinity of Cortland Academy, Homer, Cortland County. George W. Bradford. 46th Annual Report of the Regents, 66-7I. Albany I833

DELAWARE COUNTY

Plants Collected and Examined by the Botanical Class in the Delaware Literary Institute During the Summer Term of I840. M. Platt. 54th Annual Report of the Regents, 227-3I. Albany I84I

A Plant New to the State of New York and the Local Flora Range (Adoxa moschatellina). Norman Taylor. Torreya, I3:78. I9I3.

See also Flora of the Vicinity of New York by Norman Taylor.

\section{DUTCHESS COLN'TY}

Catalogue of Plants Found Growing without Cultivation in the Vicinity of Amenia Seminary, Dutchess County. A. Winchell. 64th Annual Report of the Regents, 256-79. Albany I85 I 
Flora of the Pine Ilains, Dutchess County, N. Y. I yman Henry Hoysradt. No. I. 'Torrey Club Bul., 5:46-48. I874

Catalogue of the Phaenogamous and Acrogenous Plants Growing without Cultivation within Five Miles of Pine Plains. Lyman H. Hoysradt. (Acrogens were not printed). Supplement to Torrey Botanical Club Bul., 6:32. New York, I875-79. (Published at considerable intervals, in 8 parts of 4 pages each). List of Plants of Fishkill, N. Y., and Vicinity. Winfred A. Sterns. Pamphlet, I6mo. 23 pages (I880). (His name was incorrectly spelled Winifred on the pamphlet.)

Ferns (of Poughkeepsie). Gilbert Van Ingen. Vassar Brothers Institute Trans., 5:I43-46. (I 89o)

(List of specimens in the Herbarium of Vassar Brothers Institute, collected in the county of Dutchess, N. Y.) (Gilbert Van Ingen). Vassar Brothers Institute Trans., 5:I79-92. (I890) Crataegus of Dutchess County, New York. W. W. Eggleston. Torreya, 6:63-67. I906

See also Flora of the Vicinity of New York by Norman Taylor and citations under Hudson River valley.

\section{ERIE COUNTY}

Preliminary List of the Plants of Buffalo and Its Ticinity. George W. Clinton. I7th Annual Report of the Regents on the State Cabinet (for I863), p. 24-35. Albany 1864. Also in 8vo., pamphlet, I 2 pages. Buffalo I 864

A Catalogue of the Native and Naturalized Plants of the City of

Buffalo and Its Vicinity. David F. Day; Buffalo Society of

Natural Science Bul., 4:65-279. I882-84

Also reprinted as pamphlet, $2 \mathrm{I} 5$ pages. Buffalo (I884). Second supplement in Buffalo Society Natural Science Bul., 5:85-96. 1886

Adventives at East Buffalo. John F. Cowell. Buffalo Naturalist's

Field Club Bul., I :23-24. I883

Botanical Notes. David F. Day and John F. Cowell. Buffalo

Naturalist's Field Club Bul,, I :36-40; 85-88; I I7-I8. I883 See also citations under Western New York.

\section{ESSEX COUNTY}

Plants of the Summit of Mount Marcy. Charles H. Peck. 7th Report of the Adirondack Survey, p. 40I-I2, Albany I880. Also reprinted, pamphlet, 8vo., I2 pages. I880. (Same title). 52d Report of the New York State Museum, 657-73. Albany 1899. Also in Report on the Progress of the State Land Survey (Verplank Colvin), p. I77-87. Albany I89I 
Notes on the Forest Trees of Essex, Clinton, and Franklin Counties, New York. John H. Sears. Essex Institute Bul., 13:174-88. I88I

Plants of North Elba. Charles H. Peck. New York State Museum Bul. 28, p. 67-266. Albany I899

The Crataegi of Fort Frederick, Crown Point, New York. Willard W. Eggleston. Torreya, 4:38-39. I904

A List of the Foliaceous and Fruticose Lichens Collected at Chilson Lake, Essex County, New York. Caroline W. Harris. Bryologist, 9:48-52. 1906

List of Plants Collected on Mount Marcy, August I7 and I8, I885. Hermon C. Gordinier. (Troy, N. Y.) (Date of publication not given). I p.

The Fungi of North Elba. C. H. Kauffman. New York State Museum Bul. I79, p. 80-I04. I9I5

See also citations under Adirondack mountains.

\section{FRANKLIN COUNTY}

Preliminary List of Upper St Regis Fungi. William A. Murrill. Mycologia, $7: 297-306$. November I9I5

\section{FULTON COUNTY}

(See also Paine's Flora of Oneida County)

Notes on Local Floras (Fulton County). Homer D. House. New York State Museum Bul. I76, p. 22-28. I9I5

\section{GREENE COUNTY}

A New Locality of Aspidium Aculeatum (in Stony Clove, Catskill Mountains). J. H. Redfield. American Naturalist, 3:495. I869

Catskill Ferns. Isaac H. Hall. Torrey Club Bul., 5:38-39. I874 Aspidium aculeatum at Bushnellsville Clove in the Catskill Mountains. J. H. Redfield. Torrey Club Bul., 6:331. 1879

Occurrence of Hieracium Aurantiacum in the Catskill Mountains. J. H. Redfield. Torrey Club Bul., 8:112. I88I. Proc. Phila. Acad. Nat. Sci. I88I, p. 429. I88I

See also Flora of the Vicinity of New York by Norman Taylor, and citations under Catskill mountains. 


\section{IIERKIMER COUNTY}

(See also Central New York and Paine's Flora of Oneida County, and citations under Adirondack mountains)

Flora of Honnedaga Lake. Innie Mlorrill Smith. Adirondack League Club Handbook for I894, p. 48-54. (I894)

Botany of the Little Moose Region. Annie Norrill Smith. Report of Adirondack League Club for I896, p. 54-58. (1896)

List of Plants Found on the Adirondack League Club Tract. Annie Morrill Smith. Adirondack L.eague Club Year Book for I\$98,

p. 59-72. I898. Reprinted as pamphlet, p. 59-72. I898

Some Roadside Ferns of Herkimer County, New York. Homer D.

House. Fern Bulletin, IO:I4-I6. I902

Fern Hunting in Little Falls, New York. Mrs H. A. DeCoster.

American Botanist, 5:2I-25. I903

Corrected and Enlarged List of Plants Found on the Adirondack

League Club Tract. Annie Norrill Smith. Adirondack League

Club Year Book for rgo4, p. 43-6r. (Igo4) (The Hepatics by Caroline Coventry Haynes)

A List of Trees Occurring or Likely to Occur on the Club Preserve.

B. E. Fernow. Adirondack League Club Year Book for Igo6,

p. 34-40. (I906)

A List of the Hepatics Collected in the Vicinity of Little Moose

Lake, Adirondack League Club Tract, Herkimer County, New

York. Caroline Coventry Haynes. Bryologist, 9:62-63. Igo6 Lichens of the Adirondack League Club Tract. Caroline W. Harris. Bryologist, ro:64-66. 1907

Notes on Local Floras: Herkimer County. Homer D. House.

New York State Museum Bul. I76, p. 28-29. I9I5

KINGS COUNTY

Catalogue of the Plants. Indigenous and Cultivated, Found in the Vicinity of Erasmus Hall. John Barrea Zabriskie. 48th Annual Report of the Regents, I76-8I. Albany 1835

The Plants of Prospect Park. Smith Fly Jelliffe. Brooklyn Daily

Eagle Almanac, p. 75-76. I890. (Reprinted)

A Preliminary List of the Plants Fonnd in the Ridgewood Water

Supply of the City of Brooklyn, Kings County, N. Y. Smith

Ely Jelliffe. Torrey Club Bu1., 20:243-46. June I7, I893

See also various references for the vicinity of New York under New York county and Long Island.

Trees and Shrubs of Prospect Park. T_ouis IIarman Peet. 237

pages. New York (Ig03) 


\section{LEWIS COUNTY}

A Catalogue of the Indigenous, Naturalized and Filicoid Plants of Lewis County. Franklin B. Hough. 59th Annual Report of the Regents, 249-83. Albany I 846

A Few Plants of the North Woods. Benjamin D. Gilbert. Torrey

Club Bul., 6:362-63. 1879

Plants of Bonaparate Swamp. Charles H. Peck. 53d Annual

Report of the New York State Museum, p. 858-6I. I900

The Flora of Mohawk Hill, New York, north of the Watershed.

T. A. Bendrat. Torreya, I3:45-63. I9I3

\section{MADISON COUNTY}

List of Trees and Woody Plants Growing Spontaneously in Madison and Onondaga Counties. L. M. Underwood. Geological Formations Madison and Onondaga Counties, 8vo., pamphlet, p. I6, I7. Syracuse 1879

Notes on Local Floras: Madison County. Homer D. House. New York State Museum Bul. I76, p. 29-32. I9I5

\section{MONROE COUNTY}

Catalogue of Plants and Their Time of Flowering, in and about the City of Rochester, for the year I84I. Rev. Chester Dewey. 55th Annual Report of the Regents, p. 265-72. Albany I842 Botanical Calendar Kept at Rochester. Rev. Chester Dewey. 56th Annual Report of the Regents, P. 3II-I6. Albany I 843

Mosses of Caledonia Creek. Charles H. Peck. 32d Report of the New York State Museum, p. 73-74. I879

Also in roth Report of the New York Commissioners of Fisheries.

Plants and Plant Stations (Mumford, Monroe County). E. J. Hill. Torrey Club Bul., 8:45-47. I88I

A List of the Indigenous Ferns of the Vicinity of Rochester, with Notes. Charles W. Seelye. Rochester Academy of Science Proc., I :I86-97. I891. Reprinted, with the addition of cultural notes, in Annual Report of the New York State Agricultural Society, 5I:472-9I. I892

Report of the Botanical Section, Rochester Academy of Sciences (on records for plants in the vicinity of Rochester). Miss J. H. McGuire. Rochester Academy of Science Proc., 2 :44-48. I 892

The Flora of Long Pond. A. H. Searing. Rochester Academy of Science Proc., $2: 297-300 . \quad 1895$ 
Plants of Monroe County, New York, and Adjacent Territory. Florence Beckwith and Mary L. Nacauley, assisted by Joseph B. Fuller. Rochester Academy of Science Proc., 3:I-I5O. May I896. Reprinted as pamphlet, I50 pages. June I896. Supplementary list by Florence Becliwith, Mary E. Macauley and Milton S. Baxter. Rochester Academy of Science Proc., $5:$ I -38 . I9I0

The Pinnacle Peat Marsh. H. L. Fairchild and E. G. Barnum. Rochester Academy of Science Proc., 3:20I-4. I900

Crataegus in Rochester, New York. Charles Sprague Sargent. Rochester Academy of Science Proc., 4:93-136. June 1903

Early Botanists of Rochester and Vicinity and the Botanical Section. Florence Beckwith. Rochester Academy of Science Proc., 5:39-58. I912. (Purely biographical)

Western Plants Introduced at Rochester. Homer D. House. New

York State Museum Bul. I79, p. 38-39. I9I5

See also citations under western New York.

\section{NASSAU COUNTY}

Plantae Plandomenses, or a Catalogue of the Plants Growing Spontaneously in the Neighborhood of Plandome. Casper Wister Eddy. Medical Repository II, 5:123-3I. New York 1807

List of Algae (Collected near Glen Cove). Nathaniel Lord Britton. 4th Annual Report of the State Board of Health, p. $379,380.1884$

Some Plants of the Hempstead Plains. James Kirby. American Botanist, 7:1 IO. December 1905. (Actual date of issue was several months later)

The Hempstead Plains of Long Island. Roland M. Harper. Torreya, 12:277-87. 1912. American Geographical Society Bul., 43:35I-60. May I9I I

See also various references to the vicinity of New York and particularly the Flora of the Vicinity of New York by Norman Taylor, under New York county, and Long Island.

\section{NEW YORK COUNTY}

(For vicinity of New York, see Long Island, Richmond county, Kings county, Nassau county, Bronx county, Westchester county and Queens county)

Catalogus Plantarum ()uas Sponte Crescentes in Insula Noveboraco, Observavit Johannes Leconte (John LeConte). American Medical and Philosophical Register, 2:I34-42. I8I I 
A Catalogue of Plants Growing Spontaneously within Thirty Miles of the City of New York. (John Torrey). 8vo., pamphlet, Io2 pages. Albany I8I9.

Torrey is known to have been the real author, but it was nominally prepared by a committee of three, whose names appear, namely, Torrey, Eddy and Knowles.

Synoptical View of the Lichens Growing in the Vicinity of the City of New York. Abraham Halsey. Annals Lyc. Nat. Hist., I :3-2I. I 823

Notes on Some Chenopodiaceae, Growing Spontaneously, about the City of New York. John Carey. Am. Journ. Sci. II, 7:I677I. 1849

Catalogue of Plants. Gathered in August and September, 1857, in the Ground of the Central Park. Charles Rawolle and Ig. A. Pilat. 8vo., pamphlet, 34 pages. New York I857 (List of Trees and Shrubs of Central Park). Report of the Engineer in Chief of Central Park. p. 25-35. 1857

Revised Catalogue of Plants Growing within Thirty Miles of New York City (to Gramineae). By the Torrey Botanical Club. Torrey Club Bul., v. I-5. I870-74. (William Henry Leggett)

Vo1. I : 2, 7, 8, 9-II, I5-18, 23-26, 32-34, 40-42, 47, 48. I870.

Vol. 2 : 3-6, II-I4, I9-22, 28-30, 35-37, 43, 44. I87I

Vol. 3 : 3-6, 20, 2I, 28, 29, 44-46, 52, 53. 1872

Vol. 4: 3-5, I6, I7, 23-25. 1873

Vol. $5: 28,29,36,37.1874$

List of Plants Introduced (in Vicinity of New York) with Ballast, and on Made Land. Addison Brown. Torrey Club Bul., $6: 255-58 ; 273$ (I878); 6:353-60 (I879); 7:122-26 (I880); $8: 14 \mathrm{I}-42$ (I88I)

Large Trees near New York City. W. H. Rudkin. Torrey, Club Bul., 7:107-9. I880

The Botany of a City Square (Manhattan Square). L. P. Gratacap. American Naturalist, I4:889-92. I880

The Fresh Water Flora and Fauna of Central Park, New York. L. P. Gratacap and A. Woodward. Scientific American, Supplement, December 27, I884, p. 7480-48I. Also Reprinted, pamphlet, I9 pages. 1884

Cheilanthes vestita Sw., on New York Island. E. E. Sterns. Torrey Club Bul., I5:2I I. I888 
Preliminary Catalogue of Anthophyta and l'teridophyta Reported as Growing Spontaneously within ()ne Hundred Miles of New York City. By a Committee of the Torrey Botanical Club (N. L. Britton, E. E. Sterns, Justus F. Poggenburg, Addison Brown, Thomas Conrad Porter and Charles Arthur Hollick). xviii+9o pages. Map. New York, April 25, I888

Trees and Shrubs of Central Park. xii, 363 pages. New York (March 22, 1905). Louis Harman Peet

The Poisonous Plants of the Vicinity of New York. Henry H. Rusby. Alumni Journal, College of Pharmacy, 2:307-25. I895. Reprinted, P. I-I9. I895

Some Interesting Features of Well-known Plants of New York Harbor. Carlton C. Curtis. Journal of New York Microscopical Society, i I :63-73. 1895

On Certain Bacteria from the Air of New York City. Harrison Gray Dyar. Annals of New York Academy of Science, 8:322-80. I 895

New York Ballast Grounds (and) Solanum rostratum and Argemone mexicana (two titles). W. H. McDonald. Asa Gray Bulletin, 4:65-66. I896

Botanical Collecting in the Vicinity of New York City. W. H. McDonald. Asa Gray Bulletin, 5:6-7. I897

The Passing of Port Morris. Pauline Kaufman. American Botanist, 5 :IO-I2. 1903

The Trees of a Great City. J. H. McFarland. Outlook, 82 :203-13. (Illus.) 1906

A Historical Sketch of the Development of Botany in New York City. Henry H. Rusby. Torreya, 6:IOI-I I ; I33-45. 1906 Local Flora Notes. Norman Taylor.

I Torreya, 9: 203-8. 1909

2 Torreya, 9:257-6I. 1909

3 Torreya, 10: 80-83. 1910

4 Torreya, I0: $145-49$. I910

5 Torrey Club Bul., 37 : 429-35. I9I0

6 Torreya, 10: 224-28. 1910

7 Torrey Club Bu1., $37: 559-62$. I910

8 Torreya, II : 33-36. I9II

9 Torreya, II : I70-74. I9II

io Torreya, II : I86-89. I9II

Key to the Wild Herbs Flowering in the Spring. . Chester A. Darling. Torreya, 12:46-65. I912

A Preliminary List of the Lichens Found within a Radius of One Hundred Miles of New York City. Creorge C. Wood. Torreya, I4:73-95. 1914 
Flora of the Vicinity of New York. Norman Taylor. New York Botanical Garden Memoir, 5:I-683. I9I5

Includes a radius of roo miles and hence all of Richmond county, western Long Island including part of Suffolk county, Bronx, Westchester, Putnam, Rockland, Dutchess, Orange, Sullivan, U1ster and parts of Greene and Columbia counties. Includes a "List of Local Floras of the Torrey Club Range" by John Hendley Barnhart.

The Growth-Forms of the Flora of New York and Vicinity. Norman Taylor. American Journal of Botany, 2:23-31. I9I5 Endemism in the Flora of the Vicinity of New York. Norman Taylor. Torreya, I6:I8-27. I916

\section{NIAGARA COUNTY}

(See also western New York)

A Catalogue of the Flowering and Fernlike Plants Growing without Cultivation in the Vicinity of the Falls of Niagara. David F. Day. Annual Report of the Commission for the State Reservation at Niagara, 67-133. I888. Also reprinted as pamphlet, 67 pages. Troy I888

Native Plants at Niagara Falls. John Chamberlin. Garden and Forest, 9:268. I896

Carex Tuckermani Niagarensis; a Neglected Sedge. C. P. Smith. Rhodora, I7:57-59. I9I5

ONEIDA COUNTY

(See also central New York)

A Catalogue of the Indigenous Flowering and Filicoid Plants Growing within Twenty Miles of Bridgewater, Oneida County. Asa Gray. 46th Annual Report of the Regents, p. 57-65. I 833 Catalogue of Plants Found in the County of Oneida. Peter D. Kneiskern. 55th Annual Report of the Regents, p. 273-99. Albany I 842

Catalogue of Plants Found in Oneida County and Vicinity. John A. Paine, jr. I8th Annual Report of the Regents on the Cabinet, p. 53-192. Albany I865. Also reprinted, I40 pages. Not a county flora as implied by its title. It cites definite localities from all parts of the State except the coastal islands.

Catalogue of Trees and Plants Found in the Town of Kirkland, N. Y. Amos Delos Gridley. In his History of the Town of Kirkland, New York, p. 20I-I6. New York I874

A List of Plants in the Vicinity of Utica for April, May and a Portion of June. J. V. Haberer. Pamphlet, 8vo., 20 pages. Published by the Asa Gray Botanical Society. 
Two Fern Alles in Central New York. J. V. Haberer. Fern Bulletin, 9:88-89. I90I

Dryopteris simulata, Davenport, in Central New York. H. D. House. Fern Bulletin, 9:84-85. I90 I

Two New Varieties of the Ternate Botrychiums. B. D. Gilbert. Fern Bulletin, I I :88-89. I903

Notes on the Flora of Oneida Lake and Vicinity. H. L. House. Torreya, 3:165-68: 1903

Plants of Oneida County, New York, and Vicinity. J. V. Haberer. Rhodora, 7:92-97; 106-10. 1905

Forest Conditions in Oneida County. John W. Stephen. New

York Conservation Commission Bul. 4. Albany I9I I

Notes on Local Floras: Oneida County. H. D. House. New York State Museum Bul. I76, p. 32-39. I9I5

\section{ONONDAGA COUNTY}

(See also central New York)

A Catalogue of Plants Found Growing Chiefly in the Vicinity of Onondaga Academy, Collected During the Summers of 1834 and I835. J. L. Hendrick. 5oth Annual Report of the Regents, p. 182-86. Albany I837. (Another list for I836 and I837) 5 Ist Annual Report of the Regents, p. 216-17. I 338

List of Ferns Growing in the Vicinity of Syracuse, Onondaga County, N. Y. L. M. Underwood. Case's Botanical Index, $r: 80 . \quad 1878$

The Ferns of Onondaga. Mrs S. M. Rust (Mary Oliva Rust) The Sunday Courier, March 7, I880. Syracuse. Reprint: "Filices Onondagensis." I page

The Syracuse Botanical Club (Additions to the Onondaga flora). Mary Oliva Rust. Torrey Club Bul., 9:36. I882

Apropos of Cicero Swamp. Mary Oliva Rust. Torrey Club Bul., I0:66-67. $\quad$ i 883

Additions to the Flora of Onondaga County, N. Y. Mary Oliva Rust. IO:I2I. I 883

Onondaga Indian Names of Plants. W. M. Beauchamp. Torrey Club Bul., I5:2 14; 262-66 ( 1888) ; 16:54-55 ( I889)

The Ferns of Scolopendrium Lake (Green Pond, Jamesville). L. M. Underẃood. Fern Bulletin, 5:53-54. I897

The Story of a Fern Hunt. (Feorge Duryea Hulst. Fern Bulletin, $9:$ I-2. I I I I

Outings for (Onondaga Moonwort and Slender Cliftbrake. H. E. Ransier. American Fern Journal, 2:I19-2I. I9I2 
Flora of Onondaga. Mrs L. L. H. Goodrich. 2 Io pages. Syräcuse I9I 2

Notes on Local Floras: Onondaga County. H. D. House. New York State Museum Bul. I76, 39-4I. I9I5

\section{ONTARIO COLNTY}

Blephila ciliata (L.) Raf. in Western New York. E. J. Durand. Torrey Club Bul., 20:408-9. I893

\section{ORANGE COUNTY}

Plantae Coldenghamiae in Provincia Noveboracensi Americes Sponte Crescentes, quae ad Methodum C1. Linnaei Sexualem Anno I742, etc. Obseravit et Descripsit Cadwallader Colden. Acta Societ. Reg. Sci. Upsala I743:8I-I36. I749; I744-50: 47-82. I75 I

Droseraceae and Orchidaceae of Spruce Pond, N. Y. Charles Frederick Millspaugh. Torrey Club Bul., I I : I33-34. 1884

The Violet. O. R. Willis (Description of native violets about Cornwall and proposal of several new forms). New York Military Quarterly, 4:4-6. 6 figures

The Balm of Gilead Tree (located at Balmville, Orange county). Annie Delano Hitch. 'Tree Talk, I :8. I9I3

See also Flora of the Vicinity of New York by Norman Taylor.

\section{ORLEANS COUNTY}

(See also western New York)

Hymenomycetes of Orleans County, N. Y. Charles Edward Fairman. Rochester Academy of Science Proc., 2:154-67. I893 Puff Balls, Slime Moulds and Cup Fungi of Orleans County, N. Y. Charles Edward Fairman. Rochester Academy of Science Proc., 3:206-20. Ig0o

The Pyrenomyceteae of Orleans County, N. Y. Charles Edward Fairman. Rochester Academy of Science Proc., 4:I65-9I ; fig. I-6. I905

New or Rare Pyrenomyceteae from Western New York. Charles Edward Fairman. Rochester Academy of Science Proc., 4: 21 5-24. I906

Pyrenomyceteae Novae in Leguminibus Robinae. Charles Edward

Fairman. Annals Mycology, 4:326-28. 1906

Micromycetes Americani Novi. P. A. Saccardo. Journal of Mycology, I2:47-52. Igo6 
New Fungi from New York. P. A. Saccardo. Journal of Mycology, I3:45-48. 1907

Fungi Lyndonvillensis Novi vel Minus Cogniti. Charles Edward Fairman. Annals Mycology, 8:322-32. 1910

\section{OSWEGO COUNTY}

Oswego Plants. John Herman Wibbe. Torrey Club Bul., 6:192. I 877

The Swamps of Oswego County, N. Y., and Their Flora. W. W. Rowlee. American Naturalist, 31 :690-99; 792-800. I897

The Flora of Artificial Lakes in Northern New York. W. W. Rowlee. Plant World, i :65-66. I 898

Notes on Local Floras: Oswego County. H. D. House. New York State Museum Bul. I79, p. 48-5I. I9I6

\section{QUEENS COUNTY}

(See also Long Island and New York county)

Notes from Queens County, Long Island. Julius A. Bisky. Torrey Club Bul., I4:I3-I4. I887

Additional notes by Frank N. Tillinghast, page 59.

The Trees of Flushing. Josiah Whitney Barstow. Reprinted from the Flushing Evening Journal of June 8, I893.

\section{RENSSELAER COUNTY}

A Catalogue of Plants, Growing without Cultivation, in the Vicinity of Troy. J. Wright and James Hall. 8vo., pamphlet, 42 pages. Troy 1836

Description of a Few Species of Plants from the Vicinity of Troy. H. Hurlbert Eaton. Transylvania Journal of Medical and Associated Sciences, 5:102-1O. I832. Reprint, 8 pages. ciated Sciences, 5:I02-IO. I832. Reprint, 8 pages

Flora of Rensselaer County. H. C. Gordinier and E. C. Howe. Pamphlet, 39 pages. Troy I 894

\section{RICHMOND COUNTY}

(See also New York county)

Staten Island Plants. Nathaniel Lord Britton. Torrey Club Bul., 6:177-79. I877;259-60. I878;323. I879

Flora of Richmond County. Charles Arthur Hollick and N. L. Piritton. 8vo., pamphlet, $3^{6}$ pages. 1879. Addenda in Torrey Club Bul., 7:II-I2 (I880); 8:48 (I88I); 9:I 49-5I (I882); I $2: 38-40$ (I885); I $3: 83-84$ (I886); I6:I32-34 (I889); I8:21 $3^{-14}$ (I89I) ; $22: 460-62$ (I895) 
On the Northward Extension of the New Jersey Pine Barren "Flora on Long and Staten Islands. N. L. Britton. Torrey Club Bul., $7: 81-83$. I880

A Descriptive List of Staten Island Diatoms. E. A. Schultze. Torrey Club Bul., I4:69-73; I09-I4 (I887) ; I6:98-I04 (I889) (Staten Island Trees). Charles Arthur Hollick. Natural Science Association of Staten Island Proc., February 12, I887

(Hybrid Oaks on Staten Island). Charles Arthur Hollick and W.

T. Davis. Natural Science Association of Staten Island Proc., September 8, I888

A Recent Discovery of Hybrid Oaks on Staten Island. Charles Arthur Hollick. Torrey Club Bul., I5:303-9. I888. (Reprinted, Contribution no. 8, Herbarium, Columbia College). Marine Algae of the New Jersey Coast and Adjacent Waters of Staten Island. Isaac C. Martindale. Torrey Club Memoirs, I :87-I I I. I 889

(Forms of Staten Island Plants). N. L. Britton. Natural Science Association of Staten Island Proc., November 8, I89o

List of Staten Island Fungi in the Collection of the Association. Charles Arthur Hollick and Nathaniel Lord Britton. (2 pages). August i890. Natural Science Association of Staten Island Proc., Special no. I I

List of Mosses Collected at Arlington, Staten Island, September 27, I896. Elizabeth Gertrude Britton. Natural Science Association of Staten Island Proc., 6:54. I 898

Notes on the Geology and Botany of the Fox Hills Golf Links. Charles Arthur Hollick. Natural Science Association of Staten Island Proc., 7:20-22. I899

Preliminary List of the Mosses of Staten Island. Elizabeth Gertrude Britton. Natural Science Association of Staten Island Proc., Special no. II. I890

Botanical Notes. (Additions to Lists of Staten Island Plants.) William T. Davis. Natural Science Association of Staten Island Proc., April I893; October I4, I893; $4: 83$ (I895) ; 8:5 (I9OI) ; 30-3I (I902) ; $9: 22,23$ (I904). Staten Island Association of Arts and Science Proc., I :35-37 (I906) ; 2 :I61-62 (I9I0)

List of Fungi Collected at Tottenville, October 4, I8go. Charles Arthur Hollick. Natural Science Association of Staten Island Proc., 8:25. I90I 
A Recently Introduced Cirass (Festuca capillata I amm.). Charles Arthur Hollick. Natural Science Association of Staten Island Proc., 8:I6-I7. IgoI

Local Notes on Vanishing IVild Flowers. William T. Davis.

Natural Science Association of Staten Island H'roc, 8:20-30. 1902

Notes on Our Common Stemless Blue Violets. Charles Arthur Hollick. Natural Science Association of Staten Island Proc, $8: 39$. 1902

An Undescribed Species of $\Lambda$ nnus (A. noveboracensis). Nathaniel Lord Britton. Torreya, 4:124. I904

A New Station for the Hybrid Oak, Quercus brittoni Davis. William T. Davis. Natural Science Association of Staten Island Proc., 9:38. 1905

Additions to the Flora of Staten Island. I'hilip Dowell. Natural Science Association of Staten Island Proc., 9:4I-42. (I905); 3:156-62 ( I912)

Distribution of Ferns on Staten Island. Philip Dowell. Staten Island Association Proc., I:6I-67. Igo6. 1. c. 3:I63-68. I9I2. (Notes on Some Staten Island Ferns)

The Violets of Staten Island. Philip Dowell. Torrey Club Bul., $37: 163-79 . \quad$ I910

The Flora of the Sand Barrens of Southern Staten Island. Stewart

H. Burnham. Torreya, I3:249-55. I9I3

A correction by Charles Arthur Hollick in Torreya, I3:274, 275. I9I3.

Additional Facts Concerning the Hybrid Oaks, Quercus nana $x$ Quercus marylandica (Q. brittoni Davis). William T. Davis. Staten Island Association Proc., 4:I IO, III. I9I4

See also Flora of the Vicinity of New York, by Norman Taylor.

\section{ROCKLAND COUNTY}

Some Trees and Shrubs of Rockland County. Elsie M. Kittredge. Torreya, : $3: 25-33$. I9I 3

See also Flora of the Vicinity of New York, by Norman Taylor.

\section{SARATOGA COUNTY}

Mimulus moschatus Douglas, in New York State. J. Herman Wibbe. Torrey Club Bul., 19:22, 23 (1S92) (with note by N. L. Britton on its occurrence on Long Island) 


\section{SCHENECTADY COUNTY}

Catalogue of the Flowering Plants of Schenectady County. E. W.

Paige. Svo., pamphlet, 48 pages. Albany I 865

Notes on Local Floras: Schenectady County. H. D. House. New

York State Museum Bul. I76, p. 4I, 42. I9I5

See also Paine's Flora of Oneida county.

\section{SENECA COUNTY}

(See also central New York)

Weeds (of Seneca County). John Delafield. New York State Agricultural Society Trans., I0:5I I-I6. I85I

New York State Agricultural Farm. Its Characteristics as Indicated by its General Botany. William H. Brewer. New York State Agricultural Society Trans., I8:398-406. I859

\section{STEUBEN COUNTY}

The Flora of Steuben County. Goldsmith Denniston. New York State Agricultural Society Trans., 25:I82-9I. I866

Notes on the Flora of the Upper Chemung Valley. Isabel S. Arnold. Torrey Club Bul., I5:I3I-33. I888

Notes on a Collection of Crataegus Made by Mr G. D. Cornell in the Neighborhood of Cooper Plains, Steuben County, New York. Charles Sprague Sargent. New York State Museum Bul. I22, p. 84-II5. I908

\section{SUFFOLK COUNTY}

(See also Long Island)

The Oenothera of Montauk Point, Long Island. T. F. Allen. Torrey Club Bul., I :2, 3. I870

Suffolk County Plants. Henri Wilson Young. Torrey Club Bul., $3: 5$ I, 52 (I872); 4:4I (I873)

Suffolk County Plants. Elihu Sanford Miller. Torrey Club Bul., $2: 40$ (I87I) ; $3: 56$ (I872) ; 4:4I, 42 (I873)

Catalogue of the Phaenogamous and Acrogenous Plants of Suffolk County. E. S. Miller and H. W. Young. 8vo., pamphlet, I5 pages. Port Jefferson, 1874. Addenda in Torrey Club Bul., $5: 33-34$ (I874) ; 6:I55-57; I7I-72 (I877); 6:258-59 (I878); $7: 17-18$ (1880)

A Trip to Montauk Point, Long Island. Charles Arthur Hollick. Torrey Club Bul., I8:255, 256. I 89 I 
Note's from I'lum Istand and Iisher's Island, N. I. Charles Jiurr

Graves. Torrey Club Bul., 23:59. I896

Some sand-barren l'lants of the shinnecock IIills). Willard

Nelson Clute. Plant World, I : I I, I2. 1897

Spring in the Shinnecock Hills. Willard Nelson Clute. Plant

World, 2:53-55. I899

The I'ine Barrens of Babylon and Islip. Roland M. IJarper.

Torreya, 8:I-8. Ig08

Flora of Southhold and (iardiner's Island. Stewart H. Burnham?

and Roy A. Latham. Torreya, I4:20I-25; 229-54. I9I4.

Reprinted, pamphlet

Notes on Local Floras: Suffolk County. H. D. House. New

York State Museum Bul. I76, p. 42-44. I9I5

See also Flora of the Vicinity of New York, by Norman Taylor.

TIOGA COUNTY

(See also Susquehanna region)

Catalogue of the Forest Trees Growing Wild in the Town of Nichols, Tioga Co. Robert Howell. 65th Annual Report of the Regents, p. 392-95. Albany 1852

Notes of the Flora of Cayuta Creek (Tioga County). Charles F.

Millspaugh. Torrey Club Bul., I4: I83-86. 1887

Plants of the Susquehanna Valley and Adiacent Hills of Tioga

County. Frank E. Fenno. New York State Museum Bul. 67, p.47-160. I903. Supplementary list. Frank E. Fenno. New York State Museum Bul. 75, p. 57-60. 1904

\section{TOMPKINS COUNTY}

(See also Dudley's "Cayuga Flora," listed under central New York)

List of Jlants for the State Herharium. Collected in the Vicinity of Ludlowville, Tompkins County. Henry B. Lord. Igth Annual Report of the Regents on the Cabinet. Appendix, P. 7I. I866

Preliminary Notes on Sume Vew Species of Fungi. George F.

Atkinson. Journal of Mycology, 8:1 IO-I9. I902

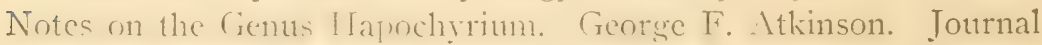
of Mycology, I0:3-8. 1904

A Mushrom Parasitic on Another Mushroom. George F. Atkinson. Plant World, IO:I2I-30. I907

The Algae of the Ithaca Marshes. II. A. Anderson. Science II, $30: 654$. November 5, 1909 
Some Fungi Parasitic of Algae. George F. Atkinson. Botanical Gazette, 48:32I-38. I909

Systematic Studies on Oenothera, III. New Species from Ithaca, New York. H. H. Bartlett. Rhodora, I5:8I-85. I9I3

\section{ULSTER COUNTY}

(See also Catskill mountains)

Notes on a Botanical Excursion to Sam's Point, U1ster Co., N. L. Britton. Torrey Club Bul., I0:I05, I06. I883

"Shongum" I-III. M. H. Pike. Garden and Forest, 5:459-60; $47 \mathrm{I}-72 ; 483-84 . \quad 1892$

Minnewaska's Flora. (Ellen Markoe Dallas). p. I-I3. I896

See also Flora of the Vicinity of New York, by Norman Taylor.

\section{WARREN COUNTY}

Forest Conditions of Warren County. F. Frank Moon. New York Conservation Commission Bul. 6. Albany, N. Y.

\section{WASHINGTON COUNTY}

Flora of Buck Mountain. Stewart H. Burnham. The Ornithologist and Botanist, II: no. 2, p. 809 (Feb.) I892. (Des Moines, Iowa)

Carices (of Vaughns, Washington County). Stewart H. Burnham.

Gray Memorial Botanical Chapter of the Agassiz Association Bul. I, p. 7-8. I893

Native Orchids. Frank Dobbin. Plant World, 3:88-89. I900

Spring in the Anaquassacook Hills. Frank Dobbin. Plant World, $4: 47-49$. I90I

Notes on the Flora of Lake George Region. Stewart H. Burnham. Torreya, $2: 27$. 1902

Notes on Epigaea repens. Stewart H. Burnham. Torreya, 4:25. I904

A Sphagnum Bog. Frank Dobbin. American Botanist, 8:5I-53. I905

A New Blueberry from New York (Vaccinium dobbini). Stewart H. Burnham. American Botanist, I2:8, 9. I907

Additional Notes on New Forms of Rudbeckia (R. hirta tubuliforme). Stewart H. Burnham. American Botanist, 20:22, 23. I9I4 


\section{WESTCHESTER COUNTY}

(See also New York county)

A Catalogue of Plants Growing Spontaneously in the Vicinity of North Salem Academy. Samuel Barnum Mead, 44th Annual Report of the Regents, p. IOI. Albany 1832

Westchester County Plants. Samuel Barnum Mead. Torrey Club Bul., $3: 40$. I872

New Lork City Stations. E. P. Bicknell. Torrey Club Bul., S:I30. IS8I. (Title misleading; station is Croton Point in Westchester county)

Report of the Flora of Westchester County. Oliver Rivington

Willis. Bolton's History of the County of Westchester (2d ed.), I :77I-826. I88I. Also reprinted, pamphlet, 56 pages.

New York I88I

Additions by Elizabeth Gertrude Britton, Torrey Club Bul., I3:6-7. 1886 Additions by E. H. Day, Torrey Club Bul., 13:94-95. I886

Additions by J. W. Martens, jr. Torrey Club Bul., I6:I23-24. I889

The Spreading of Solidago speciosa in the Vicinity of Yonkers,

New York. Mrs J. I. Northrop. Torreya, I :I4I, I42. Ig0I See also Flora of the Vicinity of New York, by Norman Taylor.

\section{WYOMING COUNTY}

$\checkmark$ A Visit to Letchworth Park. George V. Nash. Torreya, 7:209I4. 1907

Letchworth Park and Falls of the Genesee. George V. Nash. Journal of the New York Botanical Garden, 9:I88-20r. rgos The Letchworth Park Arboretum. George V. Nash. Journal of the New York Botanical Garden, I3:39-4r. I9I2

Letchworth Park and Arboretum. C. Stuart Gager. Brooklyn Botanical Garden Record, $2: 7-9$. I9I3

\section{YATES COUNTY}

Catalogue of Plants Growing without Cultivation in the Vicinity of Seneca and Crooked Lakes, in Western New York. H. P. Sartwell. 58th Annual Report of the Regents, p. 273-90. Albany I 845 


\section{INDEX 'TO CITATIONS BY ÄUTHORS}

Allen, T. F PAGE

Anderson, H. A............ 100

Arnold, Isabel S............ 99

Atkinson, George F........ I00, IOI

Ayres, Mrs George B......... 83

Bailey, William Whitman..... 8I

Barnhardt, Jiohn Hendley....82, 93

Barnum, E. G............. 90

Barstow, Josiah Whitney...... 96

Bartlett, H. H............ IOI

Baxter, Milton S............ 90

Beauchamp, W. M.......... 94

Beck, L. C............... 67

Beckwith, Florence.......... 90

Bendrat, T. A............. 89

Bennett, Henry Clay........... 84

Bicknell, Eugene P....82, 84, I02

Bisky, Julius A.............. 96

Blodgett, F. H............. $8 \mathrm{I}$

Bowman, Isaiah ........... 8I

Bradford, George W......... 85

Bray, William L........... 72

Brewer, William H......... 99

Britton, Elizabeth Gertrude..80, 82

$85,97,102$

Britton, Nathaniel Lord...8I, 90, 92 $96,97,98$, Іог

Brown, Addison...........9I, 92

Buchheister, J. C............ 80

Burgess, Edward S........... 84

Burnham, Stewart H....70, 71, 85

98, 100, I0I

Carey, John............. 9I

Chamberlin, John........... 93

Clinton, George W........68, 86

Clute, Willard Nelson. .70, 83, 84, 100

Colden, Cadwallader.......... 95

Cooke, Mordecai Cubitt...... 68

Cornell, G. D............. 99

Coville, Frederick Vernon..... 84

Cowell, John F............. 86

Curtis, Carlton C............ 92

Cushman, J. A............ 84
Dallas, Ellen Markoe.......... IOI

Darling, Chester A.......... 92

Davenport, Charles Benedict.... 82

Davis, William T.........97, 98

Day, David F............86, 93

Day, E. H............. I02

DeCoster, Mrs H. A.......... 88

Delafield, John............ 99

Denniston, Goldsmith......... 99

Dewey, Rev. Chester......... 89

Dobbin, Frank...........83, IOI

Dowell, Philip.............. 98

Dudley, William R.......... 80

Dudley, P. H...........69, 75

Durand, Elias Judah..70, 80, 83, 95

Dyar, Harrison Gray......... 92

Eaton, H. Hurlbert.......... . 96

Eddy, Caspar Wister......... 90

Eggleston, Willard W.......86, 87

Eustace, H. J............. 70

Fairchild, H. L............ 90

Fairman, Charles Edward.83, 95, 96

Fenno, Frank E..........77, 100

Fernow, B. E............. 88

Fisher, William L.......... 82

Fox, W. F.............. 70,80

Foxworthy, F. W........... 70

Fuller, Joseph B........... 90

Gager, C. Stuart..........82, 102

Gaylord, F. A.............. 7 I

Gilbert, Benjamin D......68, 70

$81,89,94$

Goodrich, Mrs L. L. H....... 95

Gordinier, Hermon C......87, 96

Gratacap, L. P............ 9I

Graves, Charles Burr......... I00

Graves, Henry S........... 80

Gray, Asa ............6.67, 93

Green, Jacob .............. 67

Gridley, Amos Delos......... 93

Grout, A. J ............ 82 
PAGE

Holl, James. ................... 87

Ilalsey, Abraham............ gi

Haberer, J. V.........8 1 , 93, 94

Harper, Roland M.......82, 90, I00

Harris, Carolyn W.........87, 88

IIarrison, Arthur............ is

Harshberger, John W........ 80

Haynes, Caroline Coventry...... 88

Hendrick, J. L.............. (4)

Hill, E. J...............83, 89

Hitch, Annie Delano.......... 95

Hollick, Charles Arthur.....92, 96

$97,98,99$

Hough, Franklin B......... 89

House, Homer D. .71, 79, 81, 84, 87

$88,89,90,94.95,96,09$, ion

Howe, E. C...........69, 76, 96

Howe, Marshall Avery....... 80

Howell, Robert ............ I00

Hoysradt, Lyman H.......... 86

Hulst, George Duryea.......81, 94

Jelliffe, Smith Ely.......82, 84, 88

Jordan, David Starr......... 80

Kalbfleisch, Augusta Schenck... 82

Kauffman, C. H..........79, 8-

Kaufman, Pauline........... 92

Kirby, James.............. 90

Kittredge, Elsie M.......... 98

Kneiskern, Peter D.......... 93

Kobbe, Frederick William..... 82

Latham, Roy A.......... I00

Leconte, John.............. (y)

Lee, Cliarles A............. 67

Leggett, William H.......68, 9I

Lord, Henry B............. I00

Lucy, T. F................ 84

Macauley, James............ 67

Macauley, Miss Mary E...... 90

McDonald W. H........... 92

McGuire, Miss J. H.......... 89

McFarland, J. II............. (9)

Markle, J. S.............. 83

Martens, J. W............. 102

Martindale, Isaac C.......... 97
PAGE

Maxon, William Ralph......80, 8I

Mead, Samuel Barnum........ 102

Mearns, Edgar A............ 80

Merrill, James H. F........ 8

Miller, Elihu Sanford........ 99

Millspaugh, Charles F...84, 95, I00

Moon, F. Frank.........81, Ior

Murrill, William A.......... 87

Nash, George V............. 102

Northrop, Mrs J. I.......... 102

Paige, E. W............... 99

Paine, John A. jr........... 93

Peck, Charles Horton. .68, 69, 70, $7 \mathrm{I}$ $72-79,80,83,86,87,89$

Peet, Louis Harman........88, 92

Pennington, L. H......... 7 , 79

Pettis, Clifford H.......... 7I

Pilat, Ig. A.............. 9I

Pinchot, Gifford............ 80

Pike, M. H.............. IоI

Pike, Nicholas............ 8 $\mathrm{I}$

Platt, M................ 85

Poggenburg, Justus F....... 92

Porter, Thomas Conrad........ 92

Prentiss, Albert Nelson........ 79

Ransier, H. E............. 94

Rawolle, Charles............ 9I

Redfield, J. H............ 87

Reed, Chester A........... 7I

Reichling, Gerard Alston...... 82

Rowlee, W. W...........8r, 96

Rudkin, W. H............ 9I

Rusby, Henry H.......... 92

Rust, Mary Oliva........... 94

Saccardo, P. A.......70, 7I, 95, 96

Sargent, Charles Sprague....70, $7 \mathrm{I}$

$$
77,78,79,83,90,99
$$

Sartwell, H. P............ 102

Schenck, George W......... 84

Schultze, E. A.............. 97

Searing, A. H............. 89

Sears, John H........... 87

Seelye, Charles W......... 89

Smith, Annie Morrill......... 88

Smith, C. P.............. 93 


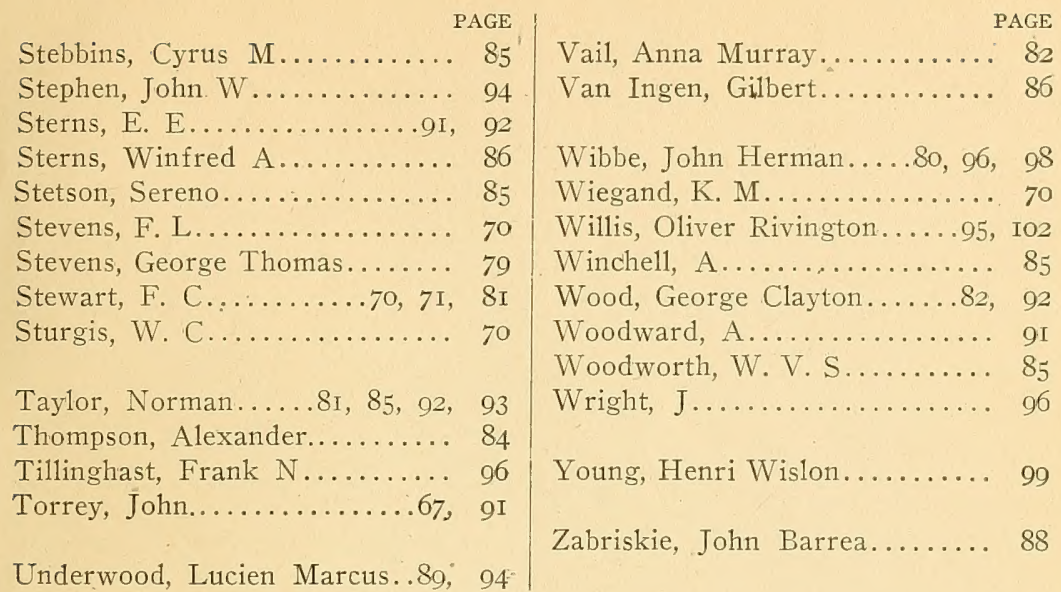





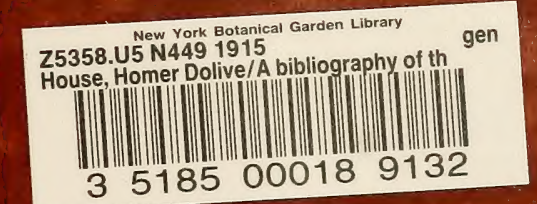




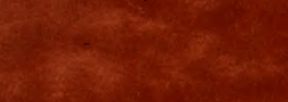

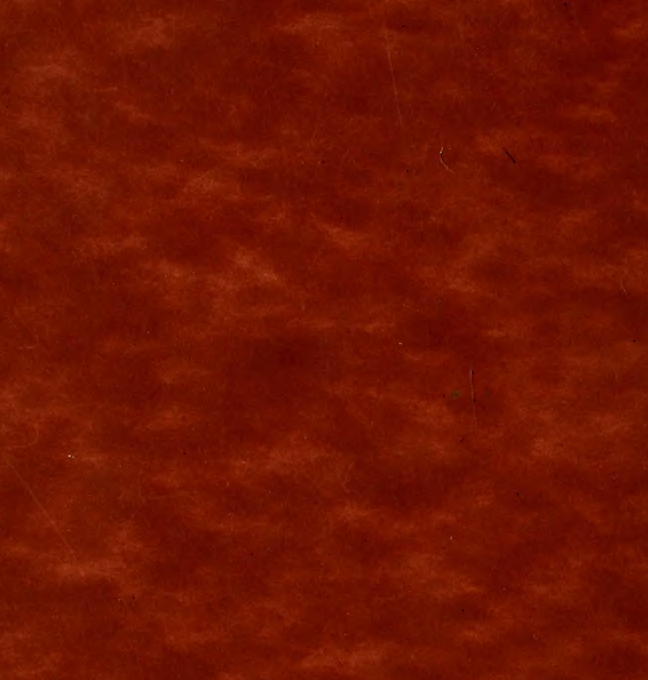

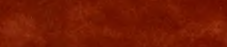

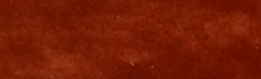

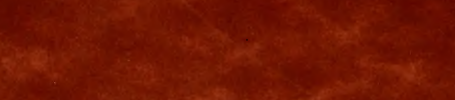

